\title{
Prestígio clínico da estatística
}

$\mathbf{P}$ ublicações em periódicos médicos, cada vez mais valorizam conclusões fundamentadas em estatísticas probabilistas. Peritos que julgam a qualidade dos artigos para publicação consideram mérito a referida inclusão. Comum nas publicações o autor indicar a significância estatística sem mais explicações, dando a maioria dos leitores, pouco entendidos no assunto, a falsa impressão de que aquele $\boldsymbol{p}$ basta para esclarecer a força decisória do contraste experimental encontrado. Entretanto, na atividade clínica é a significância prática que dá confiança ao médico em sua atividade profissional. Essa crença tem o apoio de pesquisadores e estatísticos importantes. Isso, porque sabem da interferência de fatores circunstanciais e genéticos que dificultam ou impedem o rigor desejável na composição homogênea da amostra humana; inclusive a decisão do número de seus elementos. Lembrar que a comparação dos resultados de investigações iguais, realizadas por outros médicos, é modo de reforçar a significância prática, descompasso habitual é o médico pesquisador só buscar ajuda do estatístico depois de realizada a investigação, quando o correto é a colaboração durante o planejamento. Afinal, o estatístico geralmente ignora detalhes importantes do assunto médico investigado e quais as circunstâncias reconhecidamente influentes naquilo pretendido comprovar, enquanto o médico desconhece os enredos da estatística probabilista que deseja aplicar. Recomendação atual dos estatísticos é confiar mais no intervalo de confiança do que na significância estatística.

A inauguração da estatística probabilista em Biologia aconteceu na primeira metade do século XX. Os empreendedores foram Pearson, Fisher e Student, segundo publicações no periódico Biometrika, o mais antigo e importante no assunto. Desde então, a estatística probabilista tornou-se tábua de salvação para dar mais força às conclusões das pesquisas científicas. Crédito nas opiniões de Kelvin e Galton de só haver ciência quando há números. Entretanto, a estatística probabilista em Medicina só começou sua aplicação logo depois da Segunda Grande Guerra Mundial. O impacto veio com a realização de pesquisas epidemiológicas de grande porte nos Estados Unidos, cardiovascular em Framinghan, vacina da poliomielite e uso dentário do flúor.

Menos pretensiosa e muito útil na publicação de investigações clínicas é a estatística descritiva, uso antigo. Informa proporções das freqüências de fatos, mostrada em gráficos esclarecedores, inclusive muito objetivos nas correlações e regressões. Além disso, aproveita os parâmetros da curva normal imaginada e presente naquilo que é investigado. A epidemiologia começou suas publicações nessa linha estatística e atualmente usa testes probabilistas mais elaborados. E os médicos sempre ficam mais à vontade quando raciocinam fundamentados em valores da estatística descritiva de suas pesquisas, mais fáceis de entender e acreditar, oportunidades para adotar a significância prática.

$\mathrm{O}$ autor deste editorial também ficava inseguro porque não entendia a magia decisória dos testes paramétricos e não paramétricos probabilistas encontrados nos livros. Resolvi, então, consultar as publicações dos criadores dos testes estatísticos clássicos, além de outros. Fiquei impressionado com a franqueza dos autores, jamais pretensiosos em atribuir certezas, apontavam dúvidas, sempre. Cautelosos, referiam-se aos valores probabilísticos conclusivos reduzidos à mera estimativa, sujeita percalços. Argumentavam, com clareza, sobre erros alfa e beta, hipóteses nula e alternativa, aleatoriedade na composição dos subgrupos amostrais (randomização), aumento do número de elementos amostrais para conseguir precisão e escolha do teste estatístico pertinente. Alertavam da necessidade do planejamento completo, que exige escolha adequada do teste estatístico, bem como de aplicação e interpretação corretas. Isso tudo perderia validade se alvo e métodos operacionais decididos pelo investigador fossem impróprios, o responsável pelo insucesso. 
Apesar do alívio que me deram as consultas diretas às publicações dos estatísticos idealizadores de testes probabilísticos, perdura a insegurança, devido às interferências que eles atribuem à misteriosa chance (acaso). Conceito esse herdado dos jogos de azar, que tiveram enorme influência no desenvolvimento e prestígio da estatística probabilista. Famosos matemáticos dos séculos XVIII e XIX desenvolveram aspectos importantes da teoria da probabilidade, denominada análise combinatória.

Em suma, poderíamos dizer, sem desprestígio algum, que a estatística probabilista é útil porque numericamente acena alguma certeza na prevalecente incerteza.

\author{
Almiro Pinto de Azeredo \\ Professor Catedrático de Oftalmologia \\ da Fac. Medicina de Ribeirão Preto da USP (1959 - 1981) \\ Professor Titular de Oftalmologia da UFRJ (1984 - 1991) \\ Presidente da Sociedade Brasileira de Oftalmologia (1983 - 1985)
}

